\title{
Green library - Reducing carbon footprints towards Sustainable Development in libraries: A Case Study of Federal College of Educa- tion Library, Zaria, Nigeria
}

\author{
Bibliotecas verdes - Reduzindo pegadas de carbono para o desenvolvimento sustentável em \\ bibliotecas: um estudo de caso da Federal College of Education Library, Zaria, Nigéria
}

\section{Kayode Sunday John Dada}

Department of Library and Information Science Ahmadu Bello University, Zaria, Kaduna State, Nigeria kayodescholar@gmail.com

\begin{abstract}
Carbon footprint has become a popular way of communicating climate change issues and the need to change behaviour. Reduction of environmental burden or everyday environmental actions played an important role in the day-to-day activities of libraries. Libraries are in an excellent position to be both an ecological operator and promoter of environmental awareness. The methodology employed is survey. data collected was analyzed using decision mean of 3.00. findings from the study revealed that, libraries in Nigeria are not well ground on green library requirements, due to insufficient manpower, and tools. As a result of this, this study recommends that librarians must faces the challenge of finding solutions that adequately address these issues without compromising its economic development goals and the living standards of its people through environment awareness, communication strategies and reduction on environmental burden.
\end{abstract}

\section{Keywords}

Green library. Carbon footprint. Nigerian libraries. Library infrastructure. Preservation of information resources.

\section{Resumo}

A pegada de carbono se tornou uma forma popular de comunicar as questões das mudanças climáticas e a necessidade de mudar o comportamento. A redução da carga ambiental ou ações ambientais cotidianas tiveram um papel importante nas atividades do dia-a-dia das bibliotecas. As bibliotecas estão em uma posição excelente para serem operadoras ecológicas e promotoras da consciência ambiental. A metodologia empregada é survey e os dados coletados foram analisados usando média de decisão de 3,00. As descobertas do estudo revelaram que as bibliotecas na Nigéria não estão bem fundamentadas nos requisitos de uma biblioteca verde, devido à falta de mão de obra e ferramentas. Como resultado disso, este estudo recomenda que os bibliotecários devem enfrentar o desafio de encontrar soluções que abordem adequadamente essas questões, sem comprometer seus objetivos de desenvolvimento econômico e os padrões de vida de sua população por meio da conscientização ambiental, estratégias de comunicação e redução da carga ambiental.

\section{Palavras-chave}

Bibliotecas verdes. Pegada de carbono. Bibliotecas nigerianas. Infraestrutura da biblioteca. Preservação de recursos de informação. 


\section{INTRODUCTION}

Climate change and global warming are internationally recognized as current issues, driving negative effects on humanity, and being mainly caused by Green House Gas (GHG) emissions generated both from industrial activities, and from other anthropogenic activities. Restoring the ecological balance requires urgent action to reduce GHG emissions. Libraries have long been icons of promoting sustainability through the provision of information to all and sundry. with the traditional role of libraries have sought to provide rich variety of human experience and understanding as part of their mission. one of the major challenges in the library, print collections emit a lots of carbon footprint therefore making the environment not eco-friendly (Connell, 2010).

Environmental protection has now become a major concern especially following the negative consequences and impart on the environment eco-system. A growing number of studies, research and collected data, reveal the existence of a direct relationship between climate change and carbon dioxide emissions (CO2) (IEA, 2012). According to the Fourth Assessment Report prepared by Intergovernmental Panel on Climate Change (IPCC), activities of all nations generate increasingly more GHG emissions, having significant negative impacts on climate change due to alterations taking place in the compositional level of the atmosphere, and also on rising the average global temperature since the mid of the $20^{\text {th }}$ Century (IPCC, 2007).

The main elements that generate large amounts of carbon dioxide are fossil fuels (especially oil and coal), through burning them for obtaining energy. Of all the greenhouse gases, $\mathrm{CO} 2$ has the largest share. Thus, emissions of other greenhouse gases $(\mathrm{CH} 4, \mathrm{~N} 2 \mathrm{O}, \mathrm{HFC}$, PFC, SF6) are converted in units of $\mathrm{CO} 2$ equivalent (CO2e), using the warming potential related to each gas. Among the adverse effects of GHG emissions include: global warming, decreasing water availability for humanity, pollution of air, water and soil, melting ice caps and increasing oceans level, degradation of the ozone layer, extreme weather events, changes of the seasons, reducing biodiversity, desertification in the environment.

The library role as an environmentally sound institution preceded the importance of green movement laying emphasis on the need to preserve library collections and the use of sound sustainability practices. This tradition is connected to the "reuse" and "recycle" components of the green movement. Another issue is do Nigeria libraries recycle and reused collections. The problem of reducing a library carbon footprint is perhaps the most complex and strenuous activity looking at the types of collection available in Nigeria libraries.

Though, substantive efforts have been made in preservation of library collections but none as incorporate Green Library approach in ensuring a sustainable library free from print emission as a result of light rays therefore exposing carbon footprints in the library atmosphere. Ovowoh (2010), conducted a study to assess the preservation and conservation programmes and activities in libraries in Nigeria using a survey method in information gathering in Delta State University, Abraka (DEISU) and Petroleum Training Institute (PTI) Library, Effurun. The study findings revealed that there was no written policy in the higher education institutions studied, and decisions on preservation and conservation were arbitrarily and inconsistent meaning that most libraries do not possess no written policy and staff are not adequately trained to secure library collection from deterioration using traditional methods. Asiamah (2008) carried out a similar study at Kwame Nkrumah University of Science and Technology Main Library, Ghana. The study was on preserving of print and non-print library materials. In his findings, it was revealed, that physical building, storage practices, pollution, 
light and biological agents, security of library materials as well as the poor handling of library materials were the major constraints that the university library faced in the area of preservation and conservation of library materials. Therefore, proper preservation strategies are necessary because documents were susceptible to both inherent and environmental factors.

In a case like this, libraries can approach the use of green library tool kits in preservation of library collections using recommended equipment's for library holdings, as spelt out in Green library movement toolkit in ensuring a sustainable library free of carbon footprint.

Libraries in developing countries like Nigeria are posses with a serious challenge of what kind of information resources could be collected, mere looking at the economic and academic advantage to the community it serves without a proper check if those resources are environmentally friendly through emission of carbon footprints in the library infrastructure (Dada, 2016).

This study seeks to investigate strategies used in preservation of information resources and ways of controlling carbon footprints for promoting Green Library in Libraries: A Case study of Federal College of Education Library, Zaria, Nigeria.

\section{BACKGROUND ON STUDIES ACROSS THE GLOBE}

A look at studies conducted to promote a sustainable green library across the globe. There have been movement in the promotion of Green Library across the Globe. In a study conducted by Antonelli (2008), gave a detailed insight on how library can involve themselves in green movement activities. Many information professionals in library profession have also advocated for proper library architecture and reusing of print collections such as books, recycling paper instead of shredding them and burning into open air release carbon dioxide and disrupting the ozone layer as a result of ash emission into the atmosphere (Jankowska, 2008; Kuzyk, 2008). Also, the American Library Association (ALA) saw the need of enacting a unit in the library profession, which a Task Force on the Environment (TFOE) was propagating issues related to greener libraries across the American library system. On the occasion of the 75th anniversary of IFLA, the International Federation of Library Associations and Institutions - declared that all human beings have the fundamental right to an environment adequate for their health and well-being, listing out the following objectives:

- acknowledged the importance of a commitment to sustainable development to meet the needs of the present without compromising the ability of the future,

- asserted that library and information services promote sustainable development by ensuring freedom of access to information (IFLA, 2013).

The IFLA Library Buildings and Equipment Section picked up IFLA's directive on sustainable development in their IFLA library building guidelines (Wagner \& Scherer, 2007). During the 75th IFLA World Library and Information Congress 2009 in Milan, Italy, the newly formed IFLA Special Interest Group ENSULIB (Environmental Sustainability and Libraries), sponsored by the IFLA Preservation and Conservation Section offered their first conference session, entitled "Libraries and awareness about sustainability", followed by related conference sessions in 2010-2012. From 2009 on, articles on environmental sustainability and libraries were also published in the International Preservation News, published by the IFLA Preservation and Conservation Core Activity PAC (IFLA, 2013).

At the 77th IFLA Congress 2011 in San Juan, Puerto Rico, the IFLA Library Buildings and Equipment Section hosted a conference session on "Sustainability issues in the design of 
libraries: the importance of creating environmentally responsible library facilities and spaces in the 21st century".

In addition library associations and organizations like SLA, the Special Libraries Association (Davis 2008) became aware of "green conferences"; they supported their member libraries by setting up specific groups like the Australian Library and Information Society (ALIA Sustainable Libraries Group 2010); holding conferences on green themes like the 16th Seminar of the LIBER Architecture Group held in Prague, Czech Republic 2011 (Sommer \& Feldsien-Sudhaus 2012), and the American Library Association - which has been handling this issue since the 1990s (Link, 2002) - recently started a petition for a new Sustainability Round Table to aid in the advancement and dissemination of sustainable practices.

In achieving a sustainable development in Nigerian libraries lots of issues must be addressed such as, the role of libraries as key players and promoting agent of environmental awareness with collaborative effort with experts from climate and experts by instituting policy and guidelines on the need for sustainably environment. As opined by Sonkkanen, (2012), libraries must control their cost with material and energy efficient as part of the organization global responsibility to support green library movement across the globe.

\section{DEFINITION OF CARBON FOOTPRINT}

The term "Carbon footprint" was coined in the 90's, deriving from the concept of "ecological footprint" (Ercinand Hoekstra, 2012), but addressing the measurement of the climate change impacts. The concept began to be publicized independently, since 2005 and refers to the impact of human activities on the environment and especially on the climatic conditions, in terms of greenhouse gases emissions (or briefly called "carbon emissions"). According to Wiedmann and Minx (2008), the carbon footprint is "the total amount of greenhouse gas emissions (GHG) caused by an organization, event or product".

Also, a carbon footprint is defined as the total set of greenhouse gas (GHG) emissions caused by an organization, product, event or person. In this study, the newly introduced term product carbon footprint (PCF) are used several times taking a look in the library setting. It is defined as the total set of greenhouse gas (GHG) emissions of a product across its life cycle.

Carbon footprint calculation serves as an assessment tool in terms of GHG emissions and then, it serves to manage and reduce these emissions. After calculating the carbon footprint, its detailing helps to identify weaknesses and areas of high emissions that can be eliminated or improved. Thus, carbon footprint is an indicator of sustainable development.

Internationally, numerous methodologies and models for calculating carbon footprint were developed, both on individual level or a product / service, organization / institution level but also for communities, nations and even at global level. Thus, distinguish several studies and reports on the carbon footprint, developed by various international institutions and organizations, both private (especially NGOs) as well as public, but the literature does not fully cover the topic: there are gaps both concerning its definition and its application in practice. It is observed in developing countries like Nigeria, where there are scarce resources and library patrons are very conversant with print resources. libraries can promote sustainability in a number of ways by: selecting and acquiring Energy Star compliant components (Neale, 2008) Libraries choosing recycling toner cartridges for printing, reduction in paper usage in the library, using recycled chlorine free FSC certified paper (Milliot, 2008). Encouraging the usage of more printed collections as opposed to electronic devices as calculated 
8.85 pounds of $\mathrm{CO} 2$ on paper than 11.88 pounds of $\mathrm{CO} 2$ emitted from computer devices showing that printed collection emit small amount of $\mathrm{CO} 2$ to the environment.

The carbon footprint of books comprises emissions caused by the electricity and heat production required for making the product as well as greenhouse gas emissions resulting from transport. The greenhouse gas emissions produced by a single book during its life cycle (from cradle to retailer's warehouse) correspond to a car journey of approximately 7.3 kilometres (as shown in Figure 1).

Figure 1 - The greenhouse gas emissions produced by a single book during its life cycle

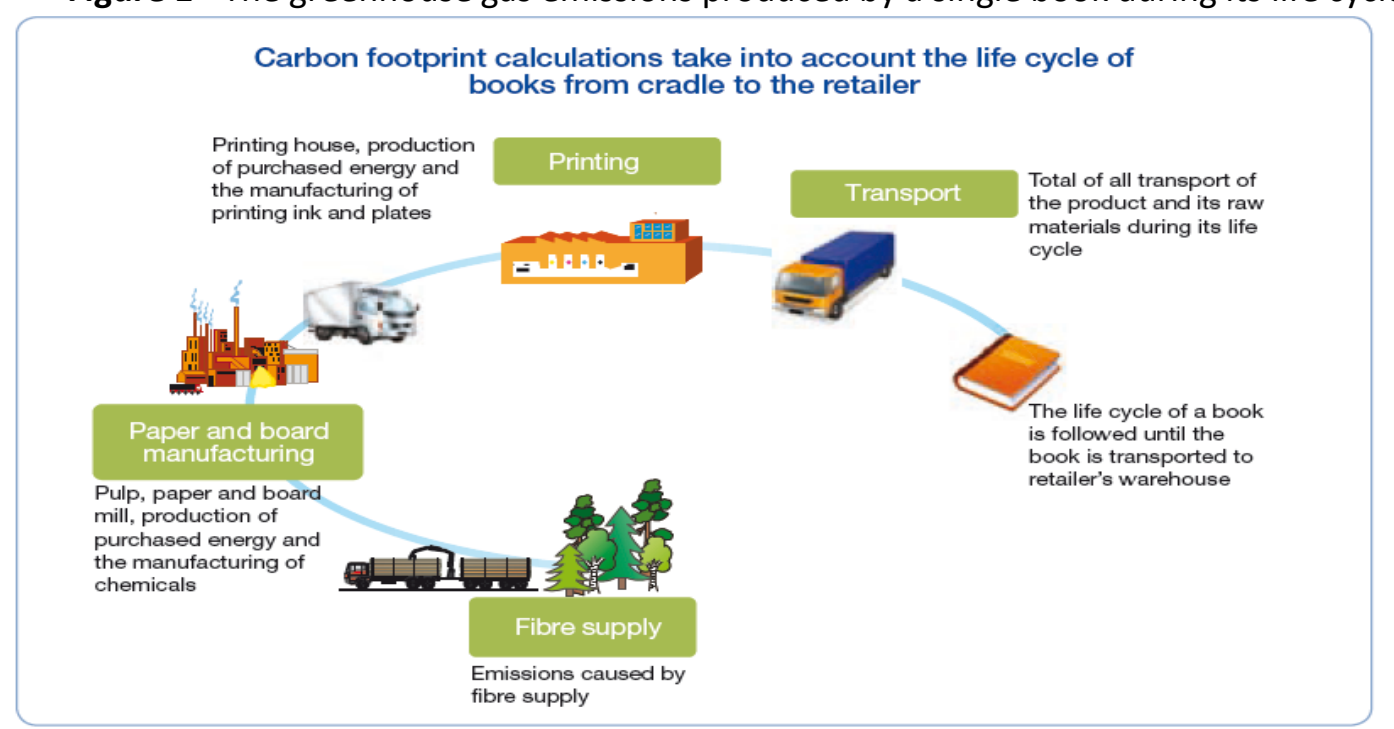

Font: Adapted from Pihkola (2010).

The above figure shows that the primary raw materials of books are paper and paperboard made of wood fibre. Wood is a renewable natural resource that binds carbon dioxide from the atmosphere. In addition to trees, forests also bind carbon dioxide through other vegetation and soil. Forests and soil also release carbon dioxide in connection with decomposition (Seppälä, 2009). Some of the carbon contained in wood is released to the atmosphere during the paper and paperboard production process, and the rest remains bound to the finished book. The carbon that remains bound to the product is released when books are incinerated or deposited in landfill sites. As paper and paperboard decompose in landfill sites, carbon dioxide and methane are formed, some of which are released to the atmosphere and some of which are recovered.

However, when the product is not discarded for a long time (more than a year), the carbon that remains bound to the product can be deemed to be reducing the carbon footprint. According to calculations produced using the PAS 2050 specification, after 5 years, the carbon that remains bound to the product reduces the carbon footprint caused by the production stage by approximately 5\%, and after 100 years, by approximately 75\% (PAS 2050, 2008).

\section{OTHER ENVIRONMENTAL IMPACTS}

In addition to the carbon footprint, it is also important to factor in any other potential environmental impacts of the production and use of books. The carbon footprint of books is mostly the result of the use of energy and fuels, but the use of energy also produces other 
emissions in addition to greenhouse gases, and these also contribute to the prevalence of acidification and particulates. Energy consumption also leads to depletion of the Earth's fossil and mineral resources. Discharges into water cause eutrophication.

Due to the multitude of models and calculation methodologies, there is no uniform or universally accepted method for calculating the carbon footprint. However, more and more companies, especially multinationals ones, are willing to make an effort to calculate the carbon footprint and to disseminate the results. In some cases, it can be observed a greater intention and a concrete mobilization on the individual and organizational level than on governmental level.

\section{METHODOLOGY}

A self-developed questionnaire was used to collect data from respondents in the library. The researcher personally administered the questionnaire to the respondents through the Head of Sections in the library. The respondents were given two days to complete and return the questionnaire to the head of section. After the stipulated days, the researcher retrieved the questionnaires. This approach was adopted in order to enhance the safety and complete return of the questionnaires.

The study adopted survey methodology. The population of the study comprises of 57 library staff care of preservation of information resources. They are categorized as follows: 23 Library Assistants, 20 Library Officers and 14 Supportive staff (FCE Library Staff List, 2016). There was no sampling procedure as the population was considered small. The researcher also used the period of distribution and collection of questionnaire to personally visit the College library to observe the various information resources available, level of deterioration and preservation activities. The researcher analyzed the collected data into frequency tables and mean decision using SPSS Statistical Package $23^{\text {rd }}$ edition.

\section{RESULTS AND DISCUSSION}

Table 1 indicates that 28 representing 49.1\% on the respondent's sex are male and the rest 29 representing $50.9 \%$ are females. The table 2 revealed that the respondents are in agree with the items that the available preservation techniques adopted in the library for preservation of information resources is the conventional way of keeping printed information resources on shelves not under proper management archival storage reason being that the cumulative mean response of 3.15 was found to be higher than the 3.00 decision mean. Specifically, the findings showed that 31 of this view attracted the highest mean response of 3.49 with details showing that while 31 were in strong agreement, 23 were in agreement as against the rest 3 in disagreement.

Table 1 - Demographic Information of the Respondents

\begin{tabular}{|l|l|l|l|}
\hline \multicolumn{3}{|l|}{ Table 1. Distribution of Respondents by: Sex } \\
\hline Gender & Frequency & Percentage (\%) \\
\hline MALE & 28 & 49.1 \\
\hline FEMALE & 29 & 50.9 \\
\hline & & \\
\hline
\end{tabular}




\begin{tabular}{|l|l|l|}
\hline Total & 57 & 100.0 \\
\hline
\end{tabular}

Table 2 - Available Preservation techniques, practices and policy of information resources in the library

\begin{tabular}{|c|c|c|c|c|c|c|c|}
\hline $\mathbf{S} / \mathbf{N}$ & Items & SA. & A & D & SD. & Mean & Std. \\
\hline 1 & $\begin{array}{l}\text { The library observes practices on reduction of environmental } \\
\text { burden }\end{array}$ & 9 & 30 & 18 & & 2.84 & .67 \\
\hline 2 & $\begin{array}{l}\text { The library adopts proper environmental management tech- } \\
\text { niques in preservation of information resources }\end{array}$ & & 20 & 9 & 28 & 3.33 & .740 \\
\hline 3 & $\begin{array}{l}\text { The library has recycle unit for printed information resources } \\
\text { in library }\end{array}$ & & 25 & 6 & 26 & 3.33 & .66 \\
\hline 4 & $\begin{array}{l}\text { The library environment is installed with air filters, air condi- } \\
\text { tioners and humidity control devices to preserve air passage } \\
\text { under a controlled condition }\end{array}$ & 32 & 11 & 14 & & 2.95 & .666 \\
\hline 5 & $\begin{array}{l}\text { The library is installed with Green Library Movement recom- } \\
\text { mendation on lighting, air ventilators to regulate atmospheric } \\
\text { moisture and reduce carbon footprints }\end{array}$ & 9 & 15 & 15 & 18 & 2.74 & 1.078 \\
\hline 6 & $\begin{array}{l}\text { The library wall is installed with Green Library Movement } \\
\text { recommended thermometer to regulate temperature in the } \\
\text { library }\end{array}$ & & 2 & 25 & 30 & 3.40 & .56 \\
\hline 7 & $\begin{array}{l}\text { The library is equipped with fire extinguishers in case of fire } \\
\text { outbreak as an emergency precaution }\end{array}$ & & 20 & 9 & & 3.33 & .86 \\
\hline 8 & $\begin{array}{l}\text { Preservation techniques used in the library is still the conven- } \\
\text { tional traditional way of preserving printed information re- } \\
\text { sources on shelves and not under controlled archival storage }\end{array}$ & -31 & 23 & 3 & & 3.49 & .601 \\
\hline & Cumulative mean & & & & & 3.15 & \\
\hline
\end{tabular}

Based on the result, it was observed that the only preservation techniques adopted in the library is the installation of fire extinguishers as this attracted a mean response of 3.33 with details showing that 28 were in strong agreement, 20 were in agreement as against the rest 9 in disagreement.

Also, it was observed that the library has not recycle unit as this attracted a mean response of 3.33 with details showing that 26 were in strong Disagreement, 25 were in agreement as against the rest 6 in disagreement. This revealed that the library does not possess a recycle unit to collect printed information resources like worn out books, obsolete materials for shredding, and could be reused as recycle packaging shopping bags, envelope, books leading to over population of deteriorated books in the library holding.

In the same vein, non-installation of Green Library Movement Recommendation thermometer is another major cause of deterioration in the library as it's attracted the second highest mean response of 3.40 with details showing that while 30 strongly disagree, 25 were in disagreement, and the rest 2 that agreed. This shows that the library is not installed with thermometers to regulate temperature as this would expose library information collections in shelves to deterioration process as a result of heat generated and exposure of carbon footprints emission in the library eco-system.

In summary, Provision of necessary preservation equipment's and setting up of recycle unit as recommended by Green Library Movement (2009) humidifiers, air filters, conditioners, air ventilators and cooling fan should be installed and monitored to reduce carbon footprints exposure and deterioration of library information resources.

\section{CONCLUSIONS AND RECOMMENDATIONS}


The libraries as a foundation of learning and information disseminator must ensure that librarians utilised green resources in various spheres in the educational system (Link, 2000).It is laudable to note that International organizations such as GHG Protocol Product Standard, DEFRA, World Resource Institute (WRI) and the World Business Council for Sustainable Development (WBCSD) have enacted policy and guidelines on Greenhouse Gas Protocol in 1998, with a mission to develop and promote internationally accepted GHG accounting and reporting standards and tools, to achieve a low emissions economy worldwide but little is known to have conducted in developing countries like Nigeria on the carbon footprints especially in Nigerian libraries. It is worth noting that studies like these is not widely deployed because of the high level of upfront investment, lack of understanding regarding their potential efficacy, lack of experience, in deployment, shortages of technical and managerial talent necessary to implement them, among other barriers in Nigeria.

The central goals of green library is to produce physical structures that from their initial conception and design recognize and demonstrate that with some thoughtful early planning the project or system can minimize the consumption of resources and negative environmental impact throughout the full life-cycle of the structure. Other important ways to reduce the carbon footprint include reducing the amount of raw materials and using materials more efficiently. This can be achieved by designing products so as to waste as little material as possible during the production process, for example. Readers can reduce the carbon footprint by recycling the product after use. This approach extends to include efficient use of energy, water, and other resources, as well as the reduction of waste, pollution and environmental degradation and management. Along with the physical characteristics and systems of the building, a green/sustainable approach to library buildings must recognizes the critical importance of protecting the building occupant's health by addressing factors such as air and lighting quality. Librarians must possess the skills and knowledge to create a balance between various information needs of clientele, as they clarify their collection development process for their library users using various approach such as information literacy skills, community's educative programmes on the need for every individual to be involve in environmental sustainability practice.

In view of these, the following strategies are recommended to control carbon footprints and address the various challenges in the library:

\subsection{Acquisition of Green Collection Development for Librarians in the Library}

Libraries must see the need of acquiring, selecting green collections to educate librarians and information professionals with tools kits to acquire foundation knowledge on Green library. In Finland, the Finish Libraries created a Finnish Sustainable Development in Libraries Project (2011-2012) to improve the ecological sustainability of public libraries by studying current sustainable development activities, creating integral operating models and policies and presenting development plans as well as developing ways of environmental communication for both the library sector and different customer segments. This project used existing expert and partnership resources as a mutual source of information and resource and involve the different interest groups in the planning and goals of sustainable development. Tool kit such as "Green@Library: Ecological sustainability of libraries" was used to train staff in training workshops (Sonkkanen et al. 2012) a publication produced by the project team to present as well as promote libraries' environmental work and also included the view of an expert on the project. The study was conducted in Nine libraries throughout Finland, the Joroinen-Juva-Rantasalmi (JRR) Library, Kemijärvi City Library, Kotka City Library, Kuusamo 
City Library, Oulu City Library - Regional Library, Porvoo City Library - Regional Library of Uusimaa. Also, in USA, New York, Metropolitan New York Library Council created a Green Librarianship Special Interest Group (SIG) to further educational goals incorporating into the school curriculum (Antonelli, 2008).

Given all of the creative greening efforts, it has showed that libraries in developing countries like Nigeria can utilise such tool kit that will assist community decision makes, library customers in developing environmental friendly system.

\subsection{Acquisition of Green Collection Development for Patrons}

Library must make spontaneous effort to ensure that Green Library Collections is accessible in the library holding and links to toolkits and resources. As recommended by America Library Association (2009), libraries must provide open forums for green clubs on environmental discussion in lecture, webinar presentation.

i. Encourage the inclusion of children on the ecology importance through poster competition and poetry events.

ii. Set library homepage on links and bookmarks to environmental issues sites

iii. Collaboration with the community and interest group in environmental concerns, issues in addressing their various information needs. eg. Libraries in Niger Delta region, can collaborate with various ethnic groups on the need for environment sustainability through massive sensitization to multinational companies in the reduction of carbon footprints through gas flaring, oil exploration changing the natural eco system of such regions.

iv. Organize training workshops and programmes in school on eco system sustenance

\subsection{Development of Recycle Section in the library}

A collection development on Recycle Section must be dedicated for storage area for the separation and collection of recyclable waste library collection for waste management regime in place.

\subsection{Installation of Emission Control Equipment in Libraries}

Nigeria Library association should formulate a policy and guidelines in libraries in $\mathrm{Ni}$ geria through the use proper Heating, Ventilating, Air-conditioning (HVAC) systems for Depleting Potential of zero.

i. A refrigerant leak detection system must be provided for chillers in the library,

ii. All thermal and acoustic insulants used in the library building must adhere strictly with the use of ozone depleting substances in both manufacture and composition

iii. The building should be installed with peak storm water flow system in case of fire outbreaks, in accordance with CSIRO Environmental Management Guidelines 1999

iv. By replacing less efficient lighting with light emitting diodes (LEDs) and compact fluorescent Lamps (CFLs), Librarian could reduce emission by 120 million tons of $\mathrm{CO2} e$ at an average (negative) abatement cost and yield energy savings up to 190 billion KWh of electricity.

\subsection{Building maintenance Structure}


The cost, complexity and odour emissions of cleaning supplies can be reduced without sacrificing cleanliness. Adopting green cleaning processes, including the use of hydrogen peroxide in various dilutions, and microfibre cloths, to simplify and improve air quality. Replace night cleaning with pre-opening and daytime cleaning to reduce electricity use.

\subsection{Encouraging librarians to see the special value of adapted buildings as a sustainabil-} ity issue

Librarians as well as architects should be encourage to think about the special value of an adapted building for library use. Sustainability should be seen as part of the corporate identity of the library, not only in relation to energy saving, but as part of the strategic aims of the library. Sustainability is more than going green. It becomes more and more obvious that to re-use, adapt and transform an old building into a library is not necessarily a bad substitute for a new building or a less than ideal solution. Librarians should be more open to the sustainability of re-use and should focus on the opportunity to transform a building to a high-level ecologically friendly library. To accept an old building may be the first step to reducing the library's ecological footprint.

\subsection{Incorporation of Sustainability Course into the Curriculum}

Sustainability courses should be incorporated and taught to students and librarians at the start of their careers, with a view that the new generation of librarians will obtain background knowledge and adopt the ideas and goals of sustainability in library buildings in transforming old library buildings into high-quality library spaces as recommended by McDonald (2007) for proper eco-friendly system.

\subsection{Collaboration with Environmental and Ecological Experts}

Libraries must collaborate with international organizations, institutions and research centers on the need for mutual collaboration on the creation of Guidelines for ecological sustainability with experts, in accordance with the best policies and examples, aiming at activities that do not clash with our environment and promote a sustainable environment.

7.9 Acquisition of human resources: a shortage of technical talent and management support would have a serious impact on the abatement opportunities to increase the supply of technical talent requires education and more experience key players such as system engineers, and architecture are not part of the Nigerian education curriculum. Nigeria lack such engineers and information professional with expertise in advanced energy-efficiency technologies, better training, regulation could be incorporated in resolving the issue to improve manager's knowledge base and experience.

\section{REFERENCES}

AMERICAN LIBRARY ASSOCIATION. Three dynamics of sustainable communities: Economy, ecology, and equity. Libraries Build Sustainable Communities, 2009. Retrieved from: http://www.ala.org/ala/memos/rts/srrt/tfoe/libsc/librariesbuildsustainablecommunitiesthre e.cfm. 
ANTONELLI, M. The Green Library Movement: An Overview and Beyond. Electronic Green Journal, n,1, v.2, 2008. Retrieved from:

http://repositories.cdlib.org/uclalib/egi/vol1/iss27/art1.

CONNELL, V. Greening the Library: Collection Development Decisions. The Journal of the New Members Round Table, n.1 v.1, 2010.

DADA, K.S.J. Assessment of preservation of information resources at federal college of education library, Zaria. Unpublished Bachelor in Library and Information Science Project, Ahmadu Bello University, Zaria, 2016.

ERCIN, A.E.; \& HOEKSTRA, A.Y. Carbon and Water Footprints - Concepts, Methodologies and Policy Responses. Paris: Publication of United Nations Educational, Scientific and Cultural Organization, 2012.

ERM. The Guide to PAS 2050:2011 - How to carbon footprint your products, identify hotspots and reduce emissions in your supply chain. London: British Standards Institution, 2011.

IEA. Environment Protection and infrastructure Operational Programme (EIOP): Environment Friendly Energy Management, IEA/IRENA Renewables Policies Database, 2012.

IFLA. Library Building and Equipment's. Retrieved from: www.ifla.org/ES/library-buildingsand-equipment, 2013.

IFLA. Statement on Libraries and Sustainable Development. Retrieved from: www.ifla.org/publications/statement-on-libraries-and-sustainable-development, 2013.

IPCC. Climate Change 2007: Mitigation. Contribution of Working Group III to the Fourth Assessment Report of the Intergovernmental Panel on Climate, New York: Cambridge University Press, 2007.

JANKOWSKA, M.A. The way i see it: A call for sustainable library operations and Services: A response to ACRLs 2007 environmental scan. C\&RL News, n.69 v.6, 2008. Retrieved from: http://www.ala.org/ala/mgrps/divs/acrl/publications/crinews.

KUZYK, R. Going Green: Lj's second design institute tackles the ins and out of Sustainable buildings. Library Journal, n.133 , v .9, ,2008.

LINK, T. Transforming Higher Education through sustainablity and environmental education. issues in Science \& Technology Librarianship, 2000. Retrieved from:

http://www.library.ucsb.edu/listl/00-spring/article4.html.

MCDONALD, A.. "The top ten qualities of good library space." In IFLA library building guidelines: Developments \& reflections, edited by K. Latimer \& H. Niegaard, p.13-29, 2007. München: Saur. 
OVOWOH, R.O. Preserving information-bearing materials in higher education institutions in Nigeria. Library Philosophy and Practice, 2010. Retrieved from:

http://www.faqs.org/periodicals201006/209501 3381.html.

PAS 2050. Specification for the assessment of the life cycle greenhouse gas emissions of goods and services. British Standards. PAS 2050, 2008.

PCF. Project. Product Carbon Footprinting - The Right Way to Promote Low Carbon Products and Consumption Habits: Berlin: PCF Pilot Project Germany, 2009.

PIHKOLA, H. Carbon Footprint and Environmental Impacts of Prints Products from cradle to grave. VVT Research Notes, n.2560, 2010. Retrieved from: http://www.vtt.fi/publications/

SEPPÄLÄ, J. Assessment of the environmental impacts of material fl ows caused by the Finnish economy with the ENVIMAT model. The Finnish Environment 20/2009. Finnish Environment Institute (SYKE), 2009. Retrieved from: http://www.ymparisto.fi /default.asp?contentid=334235\&lan=fi.

SOMMER, D. \& FELDSIEN-SUDHAUSM, I. "Nachhaltigkeit beim Bibliotheksbau: 16. LIBER Architecture Group Seminar in Prag: ein Rückblick." ABI-Technik, n.32, v.4, p.196-210, 2012 Retrieved from: www.degruyter.com/view/i/abitech.2012.32.issue-4/abitech-2012-0036/.

SONKKANEN, L. Sustainability hides in libraries: The state of ecological sustainability in libraries. A paper presented at 78th IFLA conference, Helsinki, Finland, 2012. Retrieved from: http://conference.ifla.org/past/ifla78/184-sonkkanen-en.pdf.

WAGNER, S. \& SCHERER, J. "Green building management and sustainable maintenance." In IFLA library building guidelines: Development \& Reflections, edited by K. Latimer \& H. Niegaard, p.203-214, 2007. München: Saur.

WIEDMANN, T. \& MINX, J. Ecological Economics Research Trends: Chapter 1, A Definition of Carbon Footprints, New York, Nova Science Publishers, 2008.

WRI, WBCSD. GHG Protocol Calculation Tools, 2011. Retrieved from: http://www.ghgprotocol.org/calculation-tools/faq. 